\title{
Penetrasi Ajaran Islam dalam Tradisi Pernikahan di Sinjai, 1999-2003
}

\author{
Astuti, Amirullah, Muh Saleh Madjid \\ Prodi Pendidikan Sejarah Fakultas Ilmu Sosial Universitas Negeri Makassar \\ astutialkasi98@gmail.com
}

\begin{abstract}
Abstrak
Tujuan penelitian ini untuk mengetahui latar belakang, dinamika serta dampak dari adanya penetrasi ajaran Islam dalam tradisi pernikahan di Desa Biroro Kabupaten Sinjai. Prosedur dalam penelitian ini menggunakan metode sejarah dengan tahapan: Heuristik, Kritik, Interpretasi, dan Historiografi. Hasil penelitian menunjukkan bahwa penetrasian ajaran Islam terhadap budaya lokal dalam pernikahan adat bugis di Desa Biroro disebut sebagai penetrasi kultural spiritual karena ditemukannya perembesan dan perpaduan antara budaya lokal dengan ajaran Islam sehingga budaya yang berkembang sekarang, di dalamnya mengandung nilai-nilai agama yang sakral. Kekentalan penerapan tradisi nenek moyang dalam suatu kegiatan atau upacara, misalnya upacara pernikahan yang setiap rangkaian-rangkaian acara yang berlangsung baik pra-pernikahan hingga pelaksanaan dan pasca-pernikahan semuanya penuh dengan aturan adat menjadi sebab utama gerakan penetrasian. Selanjutnya dibentuklah Korps Mubaligh sebagai perkumpulan yang akan bertugas menyampaikan serta meratakan ajaran agama Islam secara kaffah dalam masyarakat dengan metode dakwah yang lembut dan damai. Beragam respon yang dituai, pujian bahkan penolakan keras terjadi namun tidak melemahkan pergerakan mubaligh hingga terjadinya penyerangan markas Korps Mubaligh yang menjadi pelemah pergerakan. Walaupun mengalami kemunduran, ternyata ada dampak yang dirasakan atau hasil yang membekas di masyarakat yakni penyelenggaraan kegiatan sosial kemasyarakatan serta penyelenggaraan upacara atau tradisi tertentu di Desa Biroro secara berangsur-angsur dilaksanakan dengan berlandaskan pada syariat Islam.
\end{abstract}

\section{Kata kunci : Pernikahan, Mubaligh dan Biroro}

\begin{abstract}
The purpose of this study was to determine the background, dynamics and impact of the penetration of Islamic teachings in the marriage tradition in Biroro Village, Sinjai District. The procedure in this study uses the historical method with stages: Heuristics, Criticism, Interpretation, and Historiography. The results showed that the penetration of Islamic teachings on local culture in the Bugis traditional marriage in the village of Biroro is referred to as the penetration of spiritual culture because of the discovery of seepage and integration of local culture with Islamic teachings so that the culture that is developing now contains sacred religious values. The thickness of the application of ancestral traditions in an activity or ceremony, for example a wedding ceremony where every series of events that take place both pre-marriage until the implementation and post-marriage are all filled with customary rules become the main cause or background of the penetration movement. Furthermore, the Preacher's Corps was formed as an association that would be tasked with conveying and leveling the teachings of Islam in a public manner with a gentle and peaceful method of da'wah. Various responses were taken, praise and even strong rejection occurred but did not weaken the missionary movement until the attack on the headquarters of the Preacher's Corps became a weaker movement. Despite the setbacks, it turns out there is a perceived impact or footprint on the community, namely the implementation of social community activities and the
\end{abstract}


implementation of certain ceremonies or traditions in the village of Biroro which are gradually carried out based on Islamic law.

Keywords: Marriage, Missionaries and Biroro

\section{A. Pendahuluan}

Salah satu masyarakat Indonesia yang memiliki kekayaan budaya yang menarik adalah masyarakat Sulawesi Selatan. Budaya lokal di wilayah Sulawesi Selatan sampai sekarang ini masih dilestarikan sebagai warisan nenek moyang yang diwariskan secara turun-temurun agar tetap dijaga sebagai bentuk penghargaannya kepada warisan leluhur. Menurut Sartono Kartodirdjo, bahwa dalam masyarakat tradisional pola kehidupan diatur oleh kaidah-kaidah yang diterima dari nenek moyang serta dengan sendirinya dianggap berlaku terus. (Warsito, 2012)

Berkaitan dengan upacara pernikahan, biasanya dilaksanakan berdasarkan adat dan tradisi tiap-tiap suatu daerah yang merupakan hal sakral dan suci sebab berkenaan dengan ajaran agama dan budaya setempat. Adakalanya beberapa daerah tertentu mempunyai tata cara pernikahan yang hampir sama namun demikian tiap-tiap daerah menampakkan nuansa yang spesifik sehingga tetap menunjukkan perbedaan, seperti halnya di Desa Biroro yang berusaha melestarikan warisan leluhur dengan tetap melestarikan kegiatan dan upacara tradisional, misalnya dengan mempertahankan tradisi pernikahan yang berlandaskan adat istiadat setempat.

Upacara pernikahan dalam masyarakat Bugis menjadi ajang utama dimana standar yang berlaku untuk menakar status dipertegas serta bagi mereka acara pernikahan menjadi tempat mempertontonkan standar baru dalam status sosial. Bentuk-bentuk baru ini menguatkan kesadaran yang dimiliki masyarakat Bugis bahwa aspek yang paling bertahan adalah bangunan simbolik tak terlihat dan senantiasa berubah dimana drama tanpa akhir penegasan status terekspresikan. (Millar, 2018)
Hakikatnya ajaran Islam tidak menolak perkembangan kebudayaan dan adat istiadat dalam kehidupan masyarakat, sepanjang kebudayaan dan adat istiadat tersebut tidak bertentangan dengan jiwa dan norma agama. Islam hanya menolak adat istiadat dan kebudayaan masyarakat yang mengandung unsur-unsur kepercayaan yang tidak sesuai dengan ajaran Islam. Perubahan yang terjadi dengan ketentuan menerima syariat Islam dan meninggalkan budaya yang bertentangan dengan ajaran Islam namun tetap mempertahankan budaya lokal yang sesuai dengan ajaran Islam ini mengantar masyarakat menuju ke arah yang lebih baik. (Dahlan, 2013)

Bertolak dari kerangka pemikiran tersebut di atas jelas bahwa agama Islam telah mendorong terjadinya perubahan, dalam arti kata turut memperkaya, sekaligus mewarnai corak tingkah laku, sikap dan tata nilai yang kemudian menjiwai gagasangagasan penting dalam struktur kebudayaan masyarakat. Hal serupa terjadi pula di dalam masyarakat Desa Biroro, terlihat jelas dengan adanya gerakan yang dilakukan oleh para mubaligh Desa Biroro tahun 1999 yang berawal dari gagasan penyebarluasan ajaran Islam secara kaffah serta upaya meluruskan pemahaman masyarakat sesuai al-qur'an dan hadis. Selanjutnya muncul perubahan secara signifikan dalam kegiatan atau upacaraupacara tertentu masyarakat Desa Biroro. Olehnya itu penulis berharap tulisan ini dapat memberikan kontribusi dan menambah khasanah pengetahuan terkait pernikahan adat yang mengalami perubahan dan pembaharuan setelah adanya gerakan penetrasian atau perembesan ajaran Islam oleh para mubaligh di Desa Biroro. Kehadiran Korps Mubaligh di tengah masyarakat memiliki aspek historis yang cukup menarik serta menjadi salah satu faktor perubahan secara 
signifikan dalam masyarakat, terutama dalam upacara pernikahan.

Sebelumnya telah ada penulis yang mengkaji mengenai pernikahan, baik secara adat maupun sunnah diantaranya buku yang ditulis oleh Susan Bolyard Millar tahun 2018 dengan judul judul Perkawinan Bugis, membahas tentang beragam makna di balik pesta pernikahan dalam suku Bugis. (Millar, 2018) Adapun buku yang ditulis Dr. Muhammad bin Ibrahim AlHamad berjudul Trilogi Pernikahan, isinya membahas berbagai kekeliruan yang sering dilakukan dalam pernikahan serta membahas bagaimana seharusnya pernikahan dilaksanakan sesuai syariat Islam. (Ibrahim Al-Hamad, 2013) Selain buku-buku yang membahas secara khusus mengenai pernikahan, digunakan pula buku penunjang di antaranya buku dengan judul Fikih Wanita yang diterbitkan tahun 2018, penulisnya adalah Ust. Muiz al Bantani yang membahas aturan-aturan dan hukum syariat untuk kaum wanita, tata cara pernikahan sunnah hingga mengenai pembahasan rumah tangga Islami. (AlBantani, 2018) Buku dengan judul Jejak Kehadiran Sinjai Hingga Masuknya Islam penulisnya Abu Hamid, Amiruddin dan Halilintar Lathief tahun 2002 membahas seluk beluk mengenai Kabupaten Sinjai, kerajaan yang berjaya pada masanya, dan kehidupan masyarakat pasca masuknya Islam hingga metode pendidikan dan pengajaran yang dilakukan para mubaligh dalam penyebarluasan agama Islam di Sinjai. (Hamid, et al., 2002)

Adapun kajian relevan dari skripsi tentang pernikahan karya Fatmawati tahun 2007, dengan judul Adat Perkawinan Makassar di Kec. Pallangga Kab. Gowa. Fokus kajiannya pada rangkaian acara pernikahan hukum adat, sejak proses perkenalan hingga prosesi pesta pernikahan di Kec. Pallangga. (Fatmawati, 2007) Skripsi lainnya yakni berjudul Akulturasi Budaya Lokal dan Budaya Islam dalam Adat pernikahan Masyarakat Desa Kaladi Kec. Suli Barat Kab. Luwu oleh Misnayanti tahun 2016 yang membahas mengenai pernikahan adat, akulturasi Islam dalam pernikahan hingga nilai-nilai yang terkandung dalam pernikahan di Desa Kaladi Kab. Luwu. (Misnayanti, 2016) Adapun jurnal dalam kajian relevan ini yang ditulis (Manda, 2006), (Dahlan, 2013), (Hajar \& dkk., 2018), dan (Lutfiyah, 2014).

Kajian relevan mengenai pernikahan yang telah terbit pada umumnya membahas rangkaian prosesi pernikahan adat secara keseluruhan ataupun mengenai pernikahan sunnah saja. Tanpa secara spesifik membahas pernikahan adat yang dipengaruhi unsur syariat Islam yang dikenal dengan istilah pernikahan sunnah yang digagas oleh para mubaligh setempat khususnya yang terjadi di Desa Biroro Kabupaten Sinjai

\section{B. Metode Penelitian}

Metode penelitian yang digunakan ialah kualitatif. Metode ini sering digunakan dalam ilmu sejarah dan ilmu sosial lainnya dengan tujuan untuk menemukan suatu hal yang unik dan mampu mengungkapkan peristiwa yang telah terjadi di masa lampau. (Priyadi, 2012) Metode penelitian ini pulalah yang merupakan metode penelitian sejarah yang bersifat deskriptif analisis dengan tujuan untuk menemukan dan mendeskripsikan secara analitis serta menginterpretasikan terkait penetrasi ajaran Islam dalam tradisi pernikahan di Desa Biroro Kecamatan Sinjai Timur Kabupaten Sinjai.

Dalam penulisan suatu karya ilmiah tersebut. Hal ini sering di disebut sebagai metode. Metode berbeda dengan metodologi. Menurut Kenneth D.Bailey, metode adalah tehnik penelitian atau alat yang digunakan untuk mengumpulkan data. (Hamid \& Muhammad Saleh Madjid, 2008) Berdasarkan uraian di atas maka dapat disimpulkan bahwa metode sejarah merupakan tehnik dalam merekontruksi peristiwa masa lampau melalui 4 tahapan kerja yaitu heuristik (pengumpulan sumber), kritik sumber (eksternal bahan dan internal isi), interpretasi (penafsiran), dan historiografi (penulisan sejarah). 


\section{Heuristik}

Heuristik merupakan langkah awal dalam melakukan penelitian sejarah, yaitu suatau kegiatan mencari dan mengupayakan penemuan sumber untuk mendapatkan data-data atau materi sejarah serta segala yang berhubungan dengan topik penelitian. (Rochmat, 2009) Sumber sejarah tersebut dapat berupa catatan, tradisi lisan, dan dokumen-dokumen yang berhubungan dengan penelitian.

\section{Kritik}

Ketika sumber-sumber yang digunakan sudah dianggap cukup, langkah selanjutnya adalah menilai sumber tersebut untuk menyeleksi dan menguji kebenaran dan keabsahan suatu sumber, guna mendapatkan data yang otentik. Dalam kritik sumber, terdapat penekanan tertentu yang bertujuan untuk memberikan definisi kritik sumber itu sendiri. (Helius, 2012) terdapat 2 aspek yang harus diverifikasi yakni otentisitas atau keaslian sumber dan kredibilitas atau tingkat kebenaran informasi dari sumber sejarah.

Penentuan keaslian suatu sumber berkaitan dengan bahan yang digunakan dari sumber tersebut, atau biasa disebut kritik eksternal. Sedangkan penyeleksian informasi yang terkandung dalam sumber sejarah, dapat dipercaya atau tidak, dikenal dengan istilah kritik internal. Setiap sumber sejarah diperlakukan sama yakni diseleksi baik dari segi eksternal maupun internalnya. Tahap penyeleksiannya harus sistematis yakni diawali dengan kritik eksternal selanjutnya kritik internal. Jika tahap pertama suatu sumber sejarah tidak memenuhi syarat sebuah sumber sejarah (dari segi otentisitasnya) maka tidak perlu dilanjutkan ke verifikasi selanjutnya. (Hamid \& Muhammad Saleh Madjid, 2014)

\section{Interpretasi}

Pada tahap ketiga peneliti harus menafsirkan data-data yang telah diperoleh. Kemampuan interpretasi adalah menguraikan fakta-fakta sejarah menurut data temuan karena tidak ada masa lalu dalam konteks sejarah yang sifatnya aktual sehingga harus ditafsirkan melalui data-data tersebut. (Sulasman, 2014) Dalam tahap ini penulis berusaha semaksimal mungkin untuk menghasilkan interpretasi yang tidak memihak dan sesuai dengan kebaran fakta yang ada.

\section{Historiografi}

Tahap ini merupakan tahap terakhir dalam penelitian sejarah. Pada tahap ini peneliti menuliskan peristiwa sejarah tersebut dalam sebuah tulisan yang dalam penulisan, pemaparan dan pelaporan menggunakan tata cara tertentu.

\section{Tinjauan Penelitian}

Agar dapat memahami karakteristik Desa Biroro sebagai lokasi penelitian maka pada bagian ini akan diuraikan gambaran umum mengenai Desa Biroro. Data-data yang diuraikan diperoleh dari arsip Badan Pusat Statistik Kab. Sinjai dalam kurun waktu 1999-2003 dan arsip kantor Desa Biroro akhir tahun anggaran 2003.

Desa Biroro adalah salah satu desa yang berada di Kecamatan Sinjai Timur Kabupaten Sinjai. Desa ini terletak $15 \mathrm{~km}$ dari ibukota kabupaten dengan luas wilayah 5,970 ha. (Biroro, 2003) Desa Biroro berada di wilayah administrasi Kabupaten Sinjai, terdiri dari 3 dusun yakni dusun Bentengnge, dusun Biroro, dan dusun Barae. Dilihat dari batas wilayah administrasi, Desa Biroro berbatasan dengan; sebelah Utara: Desa Patalassang. Sebelah Selatan: Desa Lembang Lohe. Sebelah Barat: Desa Aska. Sebelah Timur: Teluk Lasiai

Secara geografis, Desa Biroro merupakan wilayah yang terdiri dari desa pegunungan dan desa sekitar hutan. Oleh karena itu, mayoritas penduduknya bermata pencaharian sebagai petani. Berikut beberapa rincian umum tentang kehidupan di Desa Biroro:

\section{Penduduk dan Mata Pencaharian}

Berdasarkan arsip data tentang

Desa Biroro tahun 1999 hingga tahun 2003 dapat disimpulkan bahwa jumlah penduduk di Desa Biroro mengalami dinamika atau perubahan disetiap 
tahunnya. Pada tahun 1999 jumlah penduduknya yakni 2.062 jiwa, tahun 2000 mengalami penurunan sehingga jumlah penduduk menjadi 1.982 jiwa lalu meningkat di tahun 2001 dan 2002 hingga mencapai 2.092 jiwa, namun pada tahun 2003 kembali mengalami penurunan sehingga jumlah penduduk menjadi 2.031 jiwa dengan pembagian 1.004 jiwa berjenis kelamin laki-laki dan 1.027 berjenis kelamin perempuan. (Statistik, 2003)

Selain itu, mata pencaharian yang ditekuni oleh masyarakat Desa Biroro cukup beragam didasarkan pada keadaan geografisnya serta memperhitungkan ketersediaan tanah atau lahan. Adapun jenis mata pencahariannya yakni:

a. Pertanian dengan komoditi berupa padi dan jagung;

b. Perkebunan dengan komoditi berupa pisang, keladi, coklat, merica, cengkeh, dan kelapa;

c. Peternakan dengan jenis populasi ternak berupa ayam, kambing, sapi, kuda dan kerbau;

d. Industri kecil atau rumahan misal pembuatan kue, pertukangan maupun kerajingan tangan berupa anyaman. (Biroro, 2003)

\section{Pola Perkampungan}

Pola perkampungan di Desa Biroro terlihat dari pola hidup masyarakat yang berkelompok-kelompok karena desa ini terdiri dari 3 dusun. Rumah khas dari Desa Biroro yaitu rumah panggung, ruangan rumah terdiri dari 3 bagian yakni bagian depan sebagai tempat menerima tamu, ruang tengah sebagai ruang tidur, dan ruang belakang sebagai dapur. Adapun kondisi pemukiman penduduk hingga tahun 2003 tergolong lumayan baik karena sebagian besar rumah penduduk adalah rumah panggung yang berdinding kayu, atap terbuat dari daun sagu, serta lantai terbuat dari papan. (Amiruddin, 2018) Namun terjadi pergeseran pada saat penelitian yakni rumah dibangun tanpa panggung dengan berdinding tembok dan sebagian besar lantai terbuat dari keramik.

\section{Sistem Kepercayaan}

Masyarakat Desa Biroro mayoritas beragama Islam namun kehidupan masyarakat hingga tahun 1999 masih sangat berkaitan erat dengan kepercayaan lokal masyarakat yang telah mengakar dan bersumber dari tradisi nenek moyangnya. Hal ini dimungkinkan terjadi karena saat terjadinya proses islamisasi, Islam di Desa Biroro tidak mematikan tradisi masyarakat yang telah berkembang sebelumnya, beberapa adat dan kebiasaan lokal masih berjalan beriringan bahkan lebih dominan daripada pelaksanaan ajaran agama Islam. (Alimuddin, 2018)

Kepercayaan lokal tradisional berkaitan dengan hal supranatural yakni masyarakat masih percaya akan adanya roh leluhurnya yang tetap memperhatikan tindakan anak cucunya. Sehubungan dengan hal itu, timbullah sistem persembahan kepada arwah leluhur melalui upacara selamatan maupun sajiansajian yang dilaksanakan masyarakat pada waktu dan tempat-tempat khusus. Seiring berjalannya waktu dan adanya gerakan pemerataan penyebaran ajaran Islam di Desa Biroro oleh para mubaligh pada tahun 1999 maka kepercayaan dan ritual pemujaan mulai berkurang karena lambat laun masyarakat mulai menerima dan memahami dengan baik syariat Islam dan larangan menyekutukan Allah dengan sesuatu apapun. Namun tidak dapat dipungkiri bahwa sebagian kecil masyarakat tetap melakukannya jika ada unsur yang dianggap mendesak dan salah satu solusinya yakni dengan melakukan ritual pemujaan. (Alkab, 2019)

\section{Pembahasan}

\section{Latar Belakang Gerakan Penetrasi Ajaran Islam}

a. Masuknya Kelompok Mubaligh

Pernikahan dalam Islam dianggap sebagai sesuatu yang suci serta merupakan salah satu sunnah Rasulullah yang bertujuan mendirikan keluarga yang harmonis dan sejahtera demi melanjutkan keturunan serta 
menjaga manusia agar tidak terjerumus ke dalam perbuatan keji. Hal ini sesuai dengan firman Allah dalam Q.S. Ar-Ruum (30) : ayat 21 yang terjemahannya adalah sebagai berikut:

"Dan diantara tanda-tanda kekuasaanNya ialah Dia menciptakan untukmu istriistri dari jenismu sendiri, supaya kamu cenderung dan merasa tentram kepadanya, dan dijadikan-Nya di antaramu rasa kasih dan saying. Sesungguhnya pada yang demikian itu benar-benar terdapat tanda-tanda bagi kaum yang berpikir" (Departemen Agama RI, 2002)

Pernikahan di Desa Biroro hingga tahun 1999 masih cukup terkenal dengan kekentalan penerapan tradisi nenek moyang dalam pelaksanaan suatu acara misalnya upacara pernikahan. Hal ini terlihat jelas dalam setiap rangkaian acaranya yang berlangsung secara hukum adat yang telah berlangsung secara turun temurun. (Mansur, 2018) Hal ini dilatarbelakangi oleh minimnya penyuluhan pemerintah ataupun belum adanya ceramah rutin mengenai syariat Islam dan sunnah Rasulullah secara kaffah khususnya mengenai pernikahan.

Perihal lain yang tidak dapat dipungkiri bahwa hanya segelintir orang atau pemuda Desa Biroro yang mau dan mampu mengenyam pendidikan di pensantren pada masa itu. Kebanyakan pemuda dan pemudi pada tahun 80 dan 90-an mengenyam pendidikan di sekolah umum yang dekat dari tempat tinggal orang tuanya, hal ini dikarenakan dengan tidak tinggal dan belajar di pesantren maka mereka akan tetap bisa membantu orang tuanya sepulang sekolah. (Asiah, 2019)

Faktor lain yang menjadi pemicu semangat para mubaligh Desa Biroro untuk memperkenalkan dan mengajarkan secara menyeluruh mengenai ajaran Islam, khusunya mengenai pernikahan sunnah adalah karena suatu fenomena yang banyak terjadi di masyarakat hingga tahun 1999 yakni kasus "batal menikah". Kendala utama yang sering terjadi dibalik kasus ini adalah tingkat strata sosial dan besaran uang panai yang tidak mampu disepakati kedua belah pihak. (Alkab, 2019)

Di akhir tahun 1999, muncullah pemerhati masyarakat dari kalangan mubaligh dan tokoh masyarakat yang pernah mengenyam pendidikan di pondok pesantren Puce'e, mereka diantaranya adalah Ustadz Zainuddin, Nawir dan Baharuddin yang kemudian berinisiatif untuk melakukan suatu kegiatan atau pergerakan untuk lebih memahamkan masyarakat terkait ajaran Islam secara kaffah. Adapun dorongan utama gerakan ini yakni amanah dari ilmu yang telah mereka pelajari di pondok pesantren maupun madrasah untuk disebarluaskan, terutama kepada masyarakat di tempat tinggalnya yakni Desa Biroro. (Zainuddin, 2018)

Memperhatikan keseharian dan keadaan di masyarakat, akhirnya di awal tahun 2000 para mubaligh menggagas pembentukan perkumpulan mubaligh untuk melakukan penetrasian ajaran Islam di masyarakat, walaupun gerakan awalnya hanya dilakukan ditingkatan keluarga saja. Gerakan penetrasi berlaku secara umum untuk semua aspek dan sendi-sendi kehidupan masyarakat dan terkhusus dalam upacara pernikahan yang selama ini dapat dikatakan bahwa beberapa rangkaian acaranya cukup menyimpang dari ajaran Islam. (Zainuddin, 2018)

Pernikahan dalam pandangan Islam dinilai sebagai suatu ikatan perjanjian yang diberkahi antara seorang laki-laki dan perempuan untuk menjadi halal untuk memulai hidup baru dengan mengarungi bahtera kehidupan yang panjang. Olehnya itu untuk menciptakan hubungan yang dirahmati oleh Allah maka hendaknya prosesi pernikahan dilangsungkan sesuai dengan syariat dan sesuai dengan sunnah Rasulullah. Hal ini menjadi salah satu landasan para mubaligh membidik dan memfokokuskan pula gerakannya dalam aspek pernikahan sebagai awal 
pembentukan generasi pelanjut. (Zainuddin, 2018)

Beberapa bulan berlalu, akhirnya Ustadz Zainuddin dan Nawir sebagai pelopor utama perkumpulan mubaligh mulai merekrut keluarganya diantaranya Sahyuddin dan Abbas yang merupakan keluarga dekat beliau. Hal ini untuk memudahkan pergerakan dalam melakukan ceramah atau ta'lim rutin di masjid-masjid yang ada di Desa Biroro atas kesepakatannya dengan imam masjid. Dalam ceramah yang beliau dan anggotanya sampaikan, mulailah diselipkan materi tentang bagaimana seharusnya melaksanakan upacara pernikahan sesuai tuntunan Rasulullah dan kelebihankelebihan pernikahan sunnah. Adapun rangkaian pernikahan Sunnah yang diajarkan oleh para mubaligh yakni taaruf (proses perkenalan), nazhor (melihat wanita yang hendak di lamar), khitbah (lamaran), akad nikah dan walimah (pesta pernikahan). (Alimuddin, 2018)

\section{Peranan Pemerintah dalam Penetrasi} Ajaran Islam

Pada akhir tahun 2000, Ustadz Zainuddin beserta para mubaligh lainnya memberanikan diri menghadap kepada kepala desa yang menjabat kala itu yakni Mallongi untuk meminta izin secara resmi untuk melakukan gerakan pemerataan penyebaran ajaran agama Islam dalam masyarakat Desa Biroro. Hal tersebut disambut baik oleh Mallongi sehingga dibentuklah secara resmi suatu perkumpulan sebagai bentuk persetujuan Kepala Desa Biroro yang kemudian perkumpulan itu dinamakan "Korps Mubaligh" dengan susunan pengurus inti sebagai berikut: Ketua: Nawir, Penasehat/Pimpinan tinggi: Ustadz Zainuddin, Penanggung Jawab: Mallongi. (Mallongi, 2018)

Setelah pembentukan pengurus inti, maka dilakukanlah musyawarah pada awal tahun 2001 untuk membahas secara rinci mengenai agenda-agenda apa saja yang perlu dilakukan oleh korps mubaligh demi tersebarnya ajaran Islam secara merata di masyarakat. (Zainuddin, 2018)

Seiring berjalannya waktu, merasa gerakan penetrasi ajaran Islam ini butuh bantuan secara materi untuk kelancaran kegiatannya, maka pada pertengahan 2001 Kepala Desa Biroro kemudian mengambil keputusan untuk memberikan sedikit bantuan dana kepada korps mubaligh dari dana desa yang tersisa setelah dirincikan untuk program kerja utama desa. Hal ini dibuktikan dengan dikeluarkannya SK tentang struktur korps muballig beserta besaran dana yang kemungkinan dibutuhkan dan akan disalurkan untuk setiap kegiatan-kegiatan yang akan dilaksanakan oleh Korps Mubaligh, walau dengan jumlah dana yang kecil dan tidak menentu yakni hanya disesuaikan dengan kebutuhan para mubaligh dalam melaksanakan program kerjanya, namun hal ini menjadi salah satu penujang keberhasilan program kerja Korps Mubaligh. (Mallongi, 2018)

\section{a. Srategi Korps Mubaligh dalam Melakukan Penetrasi}

Strategi dakwah merujuk pada upaya yang sistematis dilakukan dalam rangka untuk memelihara cara-cara terbaik demi mencapai tujuan dakwah. Pilihan cara tersebut tentu dengan pertimbangan dan telah melihat pada efektifitasnya dan kemungkinan resiko yang harus dihadapi di lapangan saat melaksanankan stategi yang dipilih. Hal ini penting karena dakwah bertujuan untuk melakukan perubahan terencana dalam masyarakat maka dari itu strategi diperlukan sebagai suatu metode, siasat, atau taktik untuk mencapai tujuan dengan baik. (Amin, 2009)

Strategi yang digunakan oleh Korps Mubaligh di awal gerakan penetrasiannya yakni pada awal-awal tahun 2000 tidak jauh berbeda dengan apa yang dilakukan oleh para mubaligh diberbagai daerah untuk melakukan pemerataan ajaran Islam, khusunya di daerah yang berpenduduk suku Bugis. Pendekatan secara kekeluargaan menjadi pilihan yang 
baik dan tepat mengingat karakter dari masyarakat Bugis itu sendiri yakni mereka cukup terbuka dan merasa bebas berbincang dengan keluarga atau seseorang yang telah dianggap seperti keluarga sendiri. Selanjutnya keberhasilan dalam dakwah dilingkup keluarga menjadikan Korps Mubaligh menerapkan strategi lanjutan dengan sasaran masyarakat luas yakni seluruh masyarakat Desa Biroro. Sekitar pertengahan tahun 2001 pergerakan Korps Mubaligh semakin gencar demi menjadikan masyarakat Biroro sebagai masyarakat madani yang berwawasan islami secara kokoh dan menyeluruh di semua lapisan masyarakat. (Fatmawati, 2018)

Strategi lanjutan tersebut berasal dari ilmu dan pengalaman yang telah didapatkan oleh para mubaligh yang kemudian diajukan saat pimpinan dan anggota Korps Mubaligh mengadakan pertemuan guna melakukan evaluasi dari strategi awal. Pertemuan yang dilangsungkan di rumah Ustadz Zainuddin yang merupakan markas Korps Mubaligh setelah melaksanakan shalat isya berjamaah di masjid berlangsung cukup lama dikarenakan membahas tentang evaluasi kerja dan strategi selanjutnya yang akan dilaksanakan. (Alimuddin, 2018) Adapun hasil dari pertemuan tersebut diantaranya adalah poin-poin strategi yang akan dilaksanakan kedepannya. Strategi tersebut adalah sebagai berikut:

\section{1) Strategi dengan Sasaran Akal}

Dakwah dengan menggunakan strategi ini memfokuskan sasaran pada akal pikiran masyarakat. Strategi ini mendorong mereka untuk berfikir, merenung serta mampu mengambil hikmah dari pelajaran yang disampaikan. Strategi seperti ini telah dijelaskan dalam Al-Qur'an namun dengan kata yang lain namun semakna yakni tafakkur, taamul, i'tibar, tadabbur dan istibshar.

\section{2) Strategi Tarbiyah (Pendidikan)}

Strategi ini merupakan bentuk dari sebuah proses pembebasan masyarakat dari berbagai penjara kebodohan yang melilit kemerdekaan berfikir dan kreatifitas. Adapun metode yang dilakukan yakni para mubaligh mengadakan pertemuan yang lebih intens dengan masyarakat baik dalam majelis ta'lim maupun dalam acara-acara tertentu untuk saling bertukar pikiran untuk mengarahkan pemikiran masyarakat menuju pemahaman yang sejalan dengan syariat tanpa dihalang-halangi oleh kebiasaan jahiliyah.

\section{3) Strategi dengan Sasaran Qalbu (Hati)}

Dengan menggunakan strategi ini maka dakwah yang dilakukan memfokuskan sasarannya pada aspek hati dengan menggerakkan perasaan masyarakat yang menjadi sasaran dakwah. Metode ini digunakan khususnya untuk orang-orang terpinggirkan atau marginal, kaum perempuan serta anak yatim dan lain sebagainya. Walaupun sasaran utamanya adalah kaum yang lemah namun tidak menutup kemungkinan digunakan pula untuk masyarakat secara keseluruhan. Metode yang digunakan untuk menjalankan strategi ini diantaranya adalah para mubaligh senantiasa bersedia menjadi tempat pengaduan jika ada masalah dengan memberikan pelayanan, nasihat yang mengesankan dan membimbing dengan lemah lembut agar masyarakat mau mengikuti apa yang diajarkan yang tentunya berdasarkan dalil yang sahih.

\section{4) Strategi Keteladanan atau Percontohan}

Pelaksanaan strategi ini berkaitan langsung dengan diri para mubaligh itu sendiri yakni berkaitan dengan gerak gerik, kelakuan, perbuatan dengan harapan masyarakat dapat menerima, melihat dan mencontohnya. Dakwah dengan cara ini menyajikan keteladanan secara langsung oleh para mubaligh maupun keluarganya sehingga masyarakat akan lebih tertarik mengikuti apa yang didakwahkan sebab ada bukti nyata yang dapat mereka lihat dan contoh, misalnya mengenai pernikahan sunnah yang didakwahkan oleh para mubaligh maka mereka hendaknya menerapkannya terlebih dahulu agar menjadi ajang menunjukkan keistimewaan dan kelebihan-kelebihan dalam 
menerapkan pernikahan secara sunnah. (Zainuddin, 2018)

Adapun keberhasilan yang dicapai oleh para mubaligh dalam penerapan strategi dakwah mereka dari tahun 1999-2003 dapat dilihat dari presentasi perbandingan jumlah pasangan yang melangsungkan pernikahan adat dan pernikahan sunnah di tiap tahunnya sebagai berikut:

\begin{tabular}{|l|l|l|l|l|}
\hline $\begin{array}{l}\text { N } \\
\text { o. }\end{array}$ & $\begin{array}{l}\text { Tahu } \\
\mathrm{n}\end{array}$ & $\begin{array}{l}\text { Presenta } \\
\text { se } \\
\text { Pernikah } \\
\text { an Adat }\end{array}$ & $\begin{array}{l}\text { Presenta } \\
\text { se } \\
\text { Pernikah } \\
\text { an } \\
\text { Sunnah }\end{array}$ & $\begin{array}{l}\text { Total } \\
\text { Jumlah } \\
\text { Pasang } \\
\text { an }\end{array}$ \\
\hline 1 & 1999 & $\begin{array}{l}18 \\
\text { pasangan } \\
=85 \%\end{array}$ & $\begin{array}{l}4 \\
\text { pasangan } \\
=15 \%\end{array}$ & $\begin{array}{l}22 \\
\text { pasang } \\
\text { an }\end{array}$ \\
\hline 2 & 2000 & $\begin{array}{l}11 \\
\text { pasangan } \\
=65 \%\end{array}$ & $\begin{array}{l}6 \\
\text { pasangan } \\
=35 \%\end{array}$ & $\begin{array}{l}17 \\
\text { pasang } \\
\text { an }\end{array}$ \\
\hline 3 & 2001 & $\begin{array}{l}3 \\
\text { pasangan } \\
=25 \%\end{array}$ & $\begin{array}{l}10 \\
\text { pasangan } \\
=75 \%\end{array}$ & $\begin{array}{l}13 \\
\text { pasang } \\
\text { an }\end{array}$ \\
\hline 4 & 2002 & $\begin{array}{l}5 \\
\text { pasangan } \\
=20 \%\end{array}$ & $\begin{array}{l}19 \\
\text { pasangan } \\
=80 \%\end{array}$ & $\begin{array}{l}24 \\
\text { pasang } \\
\text { an }\end{array}$ \\
\hline 5 & 2003 & $\begin{array}{l}2 \\
\text { pasangan } \\
=20 \%\end{array}$ & $\begin{array}{l}8 \\
\text { pasangan } \\
=80 \%\end{array}$ & $\begin{array}{l}10 \\
\text { pasang } \\
\text { an }\end{array}$ \\
\hline
\end{tabular}

Sumber: Hasil wawancara dengan imam desa dan petinggi korps mubaligh

Berdasarkan tingkat perkembangan besaran presentase tiap tahun maka dapat disimpulkan bahwa para mubaligh berhasil dalam penerapan strategi dan metode dakwahnya ke masyarakat Desa Biroro dalam penyebaran ajaran Islam secara kaffah. Walaupun tidak secara serta merta mencapai tahapan yang memuaskan, namun terjadi kenaikan jumlah presentase tiap tahunnya. Namun dibalik itu semua masih ada yang melangsungkan pernikahan adat ataupun dalam pernikahan sunnah masih melangsungkan beberapa prosesi adat, hal ini menandakan bahwa dibalik keberhasilan penetrasian ajaran Islam, masih terdapat kekurangan sehingga masih ada beberapa pasangan yang tetap memilih melangsungkan pernikahannya secara hukum adat. Adapun salah satu faktor kuat dibaliknya yakni mengenai strata sosial keluarganya.

\section{Reaksi Masyarakat terhadap Gerakan Penetrasi}

Desa Biroro merupakan salah satu desa yang berada dalam wilayah administrasi Kabupaten Sinjai yang terdiri atas 3 dusun yakni dusun Barae, dusun Biroro dan dusun Bentengnge. Setelah terbentuknya perkumpulan mubaligh, maka ketiga dusun yang berada di Desa Biroro tersebut menjadi sasaran penyebaran ajaran Islam secara kaffah. Mempertimbangkan banyak hal untuk memulai gerakan penetrasi, pada pertengahan tahun 2000 para mubaligh menjadikan dusun Biroro sebagai sasaran utama. Hal ini dikarenakan masyarakat di dusun Biroro lebih luwes, terbuka dan mudah menerima saran atau nasihat maupun kritikan yang disampaikan oleh para mubaligh. (Fatmawati, 2018)

Masyarakat di dusun Biroro bahkan sebelum adanya gerakan penetrasi memang tidak terlalu kental dengan adat istiadat dari nenek moyang dalam pelaksanaan suatu acara, misalnya upacara pernikahan. Dikatakan pula di dusun ini Korps Mubaligh mendapat sambutan hangat dari masyarakat atas apa yang hendak diajarkannya dibandingkan dengan respon masyarakat dari dusun lainnya. Adapun salah satu bentuk partisipasi masyarakat dusun Biroro terhadap gerakan penetrasi adalah pada akhir tahun 2000 mereka telah menyatakan kesiapan memberikan bantuan berupa materi atau non-materi ketika diperlukan misalnya ikut bergabung dalam Korps Mubaligh sertamemeberikan sedekah kepada para mubaligh untuk digunakan dalam melakukan gerakan penetrasi. (Alimuddin, 2018)

Respon yang berbeda jauh diterima para mubaligh dari masyarakat di dusun Barae dan dusun Bentengnge di awal gerakan penetrasian di tahun 2001, sebab selain membidik dusun Biroro, para mubaligh lambat laun memulai pula 
gerakannya di 2 dusun lainnya. Masyarakat di dua dusun tersebut menganggap bahwa gerakan yang dilakukan oleh Korps Mubaligh bertentangan dengan hukum adat yang selama ini membebaskan mereka menerapkan aturan yang telah berlaku turun-temurun. (Hartati, 2019) Respon dari masyarakat ini tidak menyurutkan semangat para mubaligh untuk tetap menyampaikan ajaran Islam, terutama mengenai anjuran pernikahan sunnah.

Seiring berjalannya waktu yakni sekitar pertengahan tahun 2001 sebagian besar masyarakat di dusun Barae maupun dusun Bentengnge mulai menerapkan apa yang diajarkan oleh para mubaligh, terutama dalam upacara pernikahan. Mereka menyadari bahwa dengan mengikuti ajaran Islam lebih mempermudah mereka dalam melangsungkan pernikahan sebab tidak banyak persyaratan atau aturan yang harus dipenuhi. (Asiah, 2019)

Merasakan perubahan yang signifikan di masyarakat, Korps Mubaligh semakin giat memberikan ceramah atau ta'lim rutin agar masyarakat semakin kokoh dalam menjalankan syariat Islam. Namun dibalik kegigihan itu, muncul pula kegigihan dari beberapa tetua atau tokoh masyarakat yang masih menentang hal tersebut sebab menganggap akan menghilangkan kebudayaan asli yang telah dilangsungkan secara turun temurun. (Amiruddin, 2018)

Merasakan penolakan yang dilakukan oleh tokoh masyarakat dapat menghambat kelancaran gerakan penetrasi ajaran Islam, maka korps mubaligh kemudian memutuskan untuk melakukan upaya lebih keras dan gencar. Hasil yang memuaskan pun akhirnya diperoleh dari gerakan penetrasian ajaran Islam oleh Korps Mubaligh di akhir tahun 2001 hingga tahun 2003 yakni pernikahan yang dilaksanakan di Desa Biroro hampir secara keseluruhan telah mengikuti anjuran pernikahan sunnah. (Zainuddin, 2018)

\section{E. Kesimpulan}

Berdasarkan uraian pembahasan yang telah dipaparkan pada halaman-halaman sebelumnya, maka kesimpulan yang dapat diangkat sebagai berikut:

1. Faktor yang memicu pergerakan mubaligh Desa Biroro yakni hingga tahun 1999 masyarakat di Desa Biroro masih cukup terkenal dengan kekentalan penerapan tradisi nenek moyang, pemuda dan pemudi lebih dominan mengenyam pendidikan di sekolah umum sehingga terbilang minim ilmu agama, serta banyaknya kasus "batal menikah" karena banyak hal yang dalam aturan adat harus dipenuhi dan dipertimbangkan sebelum melangsungkan pernikahan misal strata sosial maupun besaran uang panai.

2. Strategi dakwah yang digunakan yakni diawal pergerakan para mubaligh mengguanakn pendekatan secara kekeluargaan. Namun setelah cukup matang dalam hal modal ilmu dan sumber daya manusia, para mubaligh selanjutnya menggunakan strategi yang beragam. Strategi tersebut adalah strategi dengan sasaran akal, strategi tarbiyah (pendidikan), strategi dengan sasaran qalbu, serta strategi keteladanan atau percontohan.

3. Respon masyarakat atas penetrasian ajaran Islam dalam tradisi pernikahan yakni dari dusun Biroro, Korps Mubaligh mendapat sambutan baik dan hangat dari masyarakat. Berbeda halnya dengan sambutan dari masyarakat dusun Barae dan dusun Bentengnge, diawal pergerakan mubaligh mereka terbilang cukup menentang sebab menganggap dapat menghilangkan tradisi lama. Namun lambat laun mereka mulai mengikuti arahan mubaligh dengan banyak pertimbangan, diantaranya pelaksanaan pernikahan sunnah adalah sunnah Rasulullah serta 
mampu meminimalisir pengeluaran untuk pesta.

\section{DAFTAR PUSTAKA}

Al-Bantani, M., 2018. Fikih Wanita. Banten: Mulia.

Alimuddin, 2018. Wawancara di Desa Biroro [Interview] (22 September 2018).

Alkab, 2019. Wawancara di Desa Biroro [Interview] (3 Januari 2019).

Amin, S. M., 2009. Ilmu Dakwah. Jakarta: Amzah.

Amiruddin, 2018. Wawancara di Desa Biroro [Interview] (22 September 2018).

Asiah, N., 2019. Wawancara di Desa Biroro [Interview] (3 Januari 2019).

Biroro, P. D., 2003. Laporan Penyelenggaraan Pemerintah Desa Biroro. In: Sinjai: Kantor Desa Biroro.

Dahlan, M., 2013. Islam dan Budaya Lokal: Adat Perkawinan Bugis Sinjai. Jurnal Bumi, Volume I.

Departemen Agama RI, 2002. Al-Qur'an dan Terjemahannya. Semarang: Karya Toha Putra.

Fatmawati, 2007. Adat Perkawianan Makassar di Kecamatan Pallangga Kabupaten Gowa. In: Skripsi. Makassar: Universitas Negeri Makassar, p. 1.

Fatmawati, 2018. Wawancara di Kantor Desa Biroro [Interview] (16 Juli 2018).

Hajar, S. \& dkk., 2018. Tinjauan Budaya Islam Terhadap Prosesi Pernikahan Adat di Kelurahan Cikoro' Kec. Tompobulu Kab. Gowa. Jurnal Bumi, Volume XVIII.

Hamid, A., Amiruddin \& Lathief, H., 2002. Jejak Kehadiran Sinjai Hingga Masuknya Islam. Makassar: Padat Daya.

Hamid, A. R. \& Muhammad Saleh Madjid, 2008. Pengantar Ilmu Sejarah.
Ujung Pandang: Rayhan

Intermedia.

Hamid, A. R. \& Muhammad Saleh Madjid, 2014. Pengantar Ilmu Sejarah.. Yogyakarta: Ombak.

Hartati, 2019. Wawancara di Desa Kalobba [Interview] (17 Maret 2019).

Helius, S., 2012. Metodologi Sejarah. Yogyakarta: ombak.

Ibrahim Al-Hamad, M. b., 2013. Trilogi Pernikahan. Bekasi: Daun Publishing.

Lutfiyah, 2014. Relasi Budaya dan Agama dalam Pernikahan. Jurnal Bumi, Volume XII.

Mallongi, 2018. Wawancara di Desa Biroro [Interview] (25 September 2018).

Manda, D., 2006. Upacara Perkawinan Komunitas Toani Tolotang Sidrap. Jurnal Bumi, Volume III.

Mansur, 2018. Wawancara di Desa Biroro [Interview] (25 September 2018).

Millar, S. B., 2018. Perkawinan Bugis. Makassar: Ininnawa.

Misnayanti, 2016. Akulturasi Budaya Lokal dan Budaya Islam dalam Adat Pernikahan Masyarakat Desa Kaladi Kec. Suli Barat Kab. Luwu. In: Skripsi. Makassar: UIN Alauddin Makassar, p. 1.

Priyadi, S., 2012. Metode Penelitian Pendidikan Sejarah. Yogyakarta: Ombak.

Rochmat, S., 2009. Ilmu Sejarah dalam Persfektif Ilmu Sosial. Yogyakarta: Graha Ilmu.

Statistik, B. P., 2003. Penduduk Kabupaten Sinjai Akhir Tahun 2003 (Hasil Registrasi Penduduk). In: Sinjai: BPS Kab. Sinjai.

Sulasman, 2014. Metodologi Penelitian sejarah, Teori, Metode, Contoh Aplikasi. Bandung: Pustaka Setia.

Warsito, H. R., 2012. Antropologi Budaya. Yogyakarta: Ombak.

Zainuddin, 2018. Wawancara di Desa Biroro [Interview] (21 September 2018). 